\title{
SCENES WITH THE EARTH AS ACTOR: AGENCY AND THE EARLY-MODERN EARTH
}

\author{
JONATHAN REGIER \\ Ca' Foscari University of Venice \\ Dorsoduro 3484/D, 30123 Venice \\ Italy \\ jonathan.regier@unive.it
}

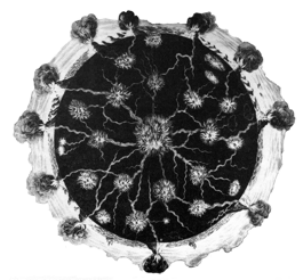

Earth Sciences History

Vol. 39, No. 2, 2020 pp. $409-419$

\begin{abstract}
This essay asks how several major figures of Renaissance and early-modern philosophy saw the Earth as agential. It argues that the Earth's agency served as a well-articulated and fundamental concept in their philosophies. That is, figures like Giordano Bruno and Johannes Kepler conceived of the Earth's agency such that it solved key problems in their cosmological systems. The essay is inspired by Bruno Latour's ecological thought, even as it acts as a corrective to certain of his assertions about early modernity. The essay concludes with some practical lessons that might be taken from early modernity.
\end{abstract}

Keywords: ecology, agency, Giordano Bruno, Johannes Kepler, Bruno Latour doi: $10.17704 / 1944-6187-39.2 .409$

In a 2014 essay, the well-known sociologist of science Bruno Latour draws from early modernity to explore how, now under the looming shadow of ecological catastrophe, we might think of the Earth as agential, as an actor in human history and society, as enjoying its own prerogatives and goals and as responding in kind (Latour 2014). Latour, here and in other recent writings and lectures, has emphasized that our vision of the Earth is presently undergoing a revolution more radical than the Copernican revolution. Then, the Earth's motion rattled the intellectual cosmos of elites, of philosophers and theologians. Now, the biosphere trembles, threatening the daily lives of every single human.

The Galileo trial marks a historical watershed for Latour, who finds inspiration in The Natural Contract by the philosopher Michel Serres. Serres saw in Galileo's strategy against the Roman Inquisition an intellectual break involving law and nature, the moment when scientists marked off a primordial territory where human law carried no authority and could not speak; from that point on, courts would have to invite scientists as experts, as mediators between the polity and a nature which preceded law and transcended it (Serres 1992, pp. 81-86). Latour takes something else from Galileo's trial, a passage from the pre-scientific to the scientific Earth. The stakes, it turns out, were more than centrality and movement. While the Earth's physical status meant so much, it was sapped of its vitality and specificity:

In order to portray the first new Earth as one falling body among all the other falling bodies of the universe, Galileo had to put aside all notions of climate, agitation, and metamorphosis [...] (Latour 2014, p. 4).

Historians of science may wince when they read the above. Galileo did not think of the Earth as falling around the Sun. That was Newton. Galileo's Sun exerted no force on the Earth; instead, planets went along on their circular orbits for reasons of design. ${ }^{1}$ But Latour may have had

Galileo thought that the Earth and other planets were in their natural places, established by God, and that circular motion was the only natural motion in the cosmos, since it allows for change while preserving the constitution and fit of the whole. This metaphysical argument is given by Copernicus in Book I of De revolutionibus orbium coelestium and connects with the design arguments in the dedication to Paul III. See Regier 2019. 
something else in mind, a series of pages in the Dialogue Concerning the Two Chief World Systems where Galileo proposes a speculative cosmogony, this in the midst of a discussion on falling bodies, rolling bodies, infinities, and geometry (Galileo 1967, pp. 21-29). In the beginning, suggests Galileo, God created all the planets in the same location and imbued them with certain tendencies of motion. Then he let each planet fall toward the centre of the universe until it reached its preordained distance and velocity, at which point He cinched the planet's linear trajectory into a perfect circle. This is surely one of the most rarefied of early-modern creation stories, also one of the most peculiar: why would a God capable of creation ex nihilo go through all these superfluous gestures? That question is hardly pertinent, since Galileo's God is really the original Galileo, releasing orbs and measuring velocities in the cosmic workshop. Behold the Deus mechanicus, a God indistinguishable from engineer; the Earth, on the other hand, is totally passive. Isn't this the Earth that most of us learned about in high-school physics (albeit with gravity and natural law replacing the divine will)? But we should also acknowledge that Galileo's Earth does not reduce to a total abstraction. In a few paragraphs, he celebrated, through the voice of the character Sagredo, those features of the Earth that supposedly excluded it from the celestial realm. "For my part," hazards Sagredo, "I consider the earth very noble and admirable precisely because of the diverse alterations, changes, generations, etc. that occur in it incessantly" (Galileo 1967, p. 58). There is simply no life without change. An Earth made of pristine ice would be sterile, superfluous; soil and earth are infinitely more valuable than diamonds, rubies and gold. A hidden fear, suggested Galileo, may lurk behind human love for the incorruptible and changeless, a "terror of death." Some men, he continued, "really deserve to encounter a Medusa's head which would transmute them into statues of jasper or of diamond and thus make them more perfect than they are" (Galileo 1967, pp. 58-59).

Nonetheless, we can rephrase Latour's point along the lines of 'classical physics fed into the de-animation of the Earth'. But what, according to Latour, was the Earth transformed from?

The European prescientific vision of the Earth saw it as a cesspool of decay, death, and corruption from which our ancestors, their eyes fixed toward the incorruptible spheres of suns, stars and God, had a tiny chance of escaping solely through prayer, contemplation and knowledge; today, in a sort of counter Copernican revolution, it is science that is forcing our eyes to turn toward the Earth considered, once again, as a cesspool of conflict, decay, way, pollution and corruption. (Latour 2014, p. 4).

If by 'prescientific' Latour means the sixteenth century, the above would be totally incorrect. Even if he means 'medieval' or 'Scholastic', it would still be misleading. Medieval literature did emphasize the lowliness of humanity and our terrestrial residence. But nature was also fundamentally good, a creation of a perfect God. In medieval bestiaries, the virtues of Christ and the Father suffuse or refract through terrestrial nature, through beasts themselves, as in the sacrifice of the pelican mother pricking her chest so that she might feed the blood to her chicks. Aquinas wrote of all living things sharing a telos: in their animal or vegetal ways, they seek to realize or perfect themselves and so imitate the perfection of God (Aquinas 1917, I.15.2.co.). In the Renaissance, new ennobling ideas about terrestrial nature arose. The Earth became, for several prominent authors, a living creature, an animal or even divine animal; in other words, it took on capacities and activities associated with animals: self-regulation, sense, movement, respiration, digestion, emotions. We can therefore talk about a specific kind of agency: like animals, the Earth could be thought to have its own prerogatives, with its health and well-being as the end goal. Terrestrial vitality remained a workable, useful notion well into the seventeenth century. Even Newton thought that the Earth resembled "a great animall or rather inanimate vegetable" which "draws in aetheriall breath for its dayly refreshment and vital ferment and transpires again wth gross exhalations" (Iliffe 2017, p. 116). The fact that Newton held such a view should signal to us that classical physics, in itself, did not necessarily exclude the possibility of an agential Earth, not any more than mechanism excluded the possibility of biological vitalism (Wolfe 2019). Instead, the de-vitalization of nature resulted from a complex of factors, as Carolyn Merchant showed in The Death of Nature; mechanism, patriarchy, state-power and capitalism supported one another 
and together asserted the dominion of men over nature (Merchant 1980). ${ }^{2}$ Lorraine Daston, in turn, has very convincingly showed the role of theology in the seventeenth-century's reduction of nature to an engine devoid of sense and intelligence - a general theological outlook that reasserted God's and humanity's dominion over nature, over "brute, passive, stupid matter" (Daston 1995). Interestingly enough, this theological outlook was shared by both Catholics and Protestants, since accusations of superstition and paganism on all sides led to a stark reaffirmation of divine will over nature. The explicit philosophical target was what we think of as the Renaissance paradigm of nature, with its web of analogy between micro- and macrocosm and its emphasis on the divine as immanent in nature. ${ }^{3}$

The agency of the Earth (which I will also refer to as 'terrestrial agency') was not just an ambient zeitgeist, nor a mere product of medieval and Renaissance political realities. In the next few pages, I would like to sketch out how it could be a solution; terrestrial agency could be formulated with specificity and force as a response to fundamental problems within natural philosophy, problems that concerned, specifically, the niceties of large-scale causation. Authors invoked it understanding that Aristotle had denied life to the Earth, and it served as a cornerstone in their novel philosophies. The subjects of this study will not be minor figures, but notorious exponents of a living Earth, primarily Giordano Bruno and Johannes Kepler (along with a brief discussion of William Gilbert). I have chosen them because, as well studied as they are, I believe we still have something to learn by asking, specifically, about natural agency — something to learn about them and some insight into our own changing views on the Earth as actor.

Before we get to Bruno and Kepler, we should start with the great re-animation of the Earth that took place when humanist translation, publication and commentary made alternatives to Aristotelian nature widely available. ${ }^{4}$ The Aristotelian Earth was an elemental conglomerate, the result of a downward tendency shared by earth and water. But Aristotle also ascribed some vitality to our globe in order to explain spontaneous generation. A vital heat resided in the air, thought Aristotle, and when trapped in water or earth, this heat informed matter, giving rise to lowly plants and animals. It is unclear what physical mechanism Aristotle had in mind. He compared the vital heat to a soul permeating the sublunar world and clearly believed it to be analogous to celestial aether and identical to the generative heat in animal semen (On the Generation of Animals, III.11.762a9-762a32; Freudenthal 1995, pp. 116-118). Interpretations of vital heat abounded among later Aristotelians (Freudenthal 1995, pp. 6, 195-207), some of them identifying it with a Timaeus-style World Soul (Hirai 2011, pp. 274-275). Scholastics generally denied any appeal to a world soul, just as they denied any soul to the earth. They preferred explaining spontaneous generation by celestial forces acting on diverse kinds of matter (Des Chene, pp. 24-25, 56).

Much stronger views on the Earth's vitality and capacities became possible in the wake of Marsilio Ficino's Platonic translations and commentaries. Now, the first question is why? After all, Plato did not seem to have much to say about a living Earth or Earth soul in, for example, the Timaeus, although he did call the Earth, "our nurse" and "the eldest of all the gods which have come into existence within the Heaven" (Plato 1925, 40b-c). Here, as elsewhere, Ficino followed Plotinus, who had carefully articulated and answered questions left open by the Timaeus on what kind of soul the Earth might possess. The one caveat here is that both Ficino and Plotinus speak of the soul belonging to the element earth, but this detail changes little for our purposes, since they meant by 'earth' the entire variegated globe, with the exception of the watery expanses that benefited from a general water soul. Plotinus considered the Earth as a divine animal imbued with intelligence and comparable to celestial bodies (Plotinus 2018, 4.4.22, p. 440). Its three levels of soul-vegetal, animal and intellectual-supported corresponding forms of life. What kind of agency did Plotinus give the Earth soul? Its divinity meant that it was "good in every way"; it was

For an appraisal of the The Death of Nature, along with its reception and influence, see Park 2006.

Consider, for instance, Gassendi's criticism of the anima mundi in Robert Fludd's philosophy as a contradiction of divine simplicity and immutability; Gassendi 2016. For an interesting discussion of how Gassendi's critique lived on to inspire Pierre Bayle's attacks on Spinoza, see Darmon 1994.

4 For an overview on the history of the Earth as an animal, and on the natural philosophical uses of terrestrial vitalism, from Plato and the Stoics to Campanella, see López 1999. 
virtuous because it supported life and, specifically, responded to the different requirements of life inside and atop it. Plotinus wrote of the Earth soul "ordering" human affairs, to the extent that they fell in its purview; clearly, he had agricultural cycles in mind, explaining that some people refer to the earth soul as Demeter, the goddess of agriculture (Plotinus 2018, 4.4.26, pp. 444-446). No less an authority on Plotinus than John M. Dillon notes the similarities between the Plotinian earth soul and James Lovelock's Gaia; both have a kind of internal awareness and capacity toward selfregulation (Plotinus 2015, pp. 403-404). However, the resemblance is not complete. The Plotinian Earth is not only aware of its physical surroundings, it also responds to human prayers and entreaties. In other words, the Plotinian Earth is a polytheistic deity. Ficino sought to harmonize Platonism and Neoplatonism with Catholic doctrine. Hence, he muted polytheistic overtones in his exposition of the Earth soul (we don't pray to Ficino's Earth), all while conserving its basic function of creating and thinking for the sake of life and humanity. In Book IV of the Platonic Theology, he gave the Earth soul its most sustained treatment, calling it the "mother substance" (substantia genitricis) that generates and vivifies. This mother substance is also intellective, possessing the "rational idea" or "principle" of whatever it produces, whether a vine or a housefly. Ficino's Earth soul is not responsible, obviously, for the generation of all terrestrial life. Instead, it is highly occupied with vegetal life; when plant seeds are not available, it takes the initiative to generate plants itself. It also produces minerals and "lower" animals, insects, frogs, mice, and the like. Ficino even suggested that, under circumstances of great need, it could generate higher animals (an idea openly embraced by Bruno). The Earth soul, then, fills in wherever it finds a dearth of vitality, creating life from the lifeless, dynamism from the inert. One conclusion to draw from Ficino's writings on the Earth soul is that plants and animals, alone, cannot by themselves preserve life across the globe. Where natural conditions and catastrophes would otherwise wipe life out, the Earth soul ensures perseverance. (Ficino 2001, IV.1, pp. 248-259).

Ficino's revival of Plato was likely the single most important factor behind the revitalization of nature among sixteenth-century natural philosophers. But it was not the only one. Stoic natural philosophy became widely available through works of Cicero, Seneca and Pliny (Barker 1991 and 2008). The Stoics also envisioned celestial bodies as alive, the Earth as an animal or something analogous, and the Earth and heavens in a reciprocal relationship, where the vapours of the Earth feed the celestial bodies that in turn provide light and warmth (e.g., Cicero 1967, II.33, p. 203). As Peter Barker describes this relationship, "the fundamental substance [pneuma] flows inwards from the boundary of the cosmos to the center and outwards again" (Barker 2008, p. 268). Copernicus himself drew from Platonic and Stoic sources (Knox 2005). Meanwhile, his readers picked up hints in Copernicus's magnum opus that suggested the Earth might be alive, capable of self-cohesion and movement because it had an animal soul (Regier 2019).

Giordano Bruno feasted on the new intellectual possibilities of his time. Taking his cue from Copernican astronomy and his own uniquely radical view of theology, he taught that the universe was infinite, filled with an infinite number and variety of creatures, and that God was immanent within it; this teeming natural infinity, Bruno asserted without much qualification, offers a far more veridic and 'heroic' knowledge of God than Christianity. Bruno represents the extreme end of the spectrum of sixteenth-century natural theology, where knowledge of God could be sought through philosophical reasoning applied to nature-even if God "in His absolute nature, essence and substance" remains utterly hidden from created beings. ${ }^{5}$ For Bruno, as for Kepler, the life of nature was as much a theological fact as anything else. When, nowadays, we hear Christians speak of a 'living God', we may imagine that life as totally abstract, as a figure of speech. A richer web of meaning was available in early modernity: living things, often including the mineral, were better than non-living; God was the highest form of life; and all life, from lowest upward, imitated God's life. The organic - the growing, breathing, bleeding, and active - issued from the divine fount of life and bore its image. It was a causal principle of Bruno's physics that the cosmos and its main constituents should be alive. He unambiguously thought of celestial bodies as big animals. ${ }^{6}$ Hence,

Created beings can know God only insofar as He is reflected in the world. See Bruno 1889, p. 79 ("Relatio").

On the "animality" of the Earth and the geo-kinetic implications, see Bruno 1994, pp. 173-177. 


\section{JONATHAN REGIER}

planets could propel themselves around their stars. Even more deeply, planetary life responded to the fundamental problems of eternity and orderly change. In Aristotelian philosophy, the cosmos has no beginning nor end. How does it remain viable through such spans of time? The answer for an Aristotelian is that incorruptible celestial bodies govern the cycles of nature; they never blow up, drift off course, or fade away. But a special celestial matter makes no sense in Bruno's framework, as everything is composed of the same basic stuff, an eternal but ceaselessly changing primary matter (Bruno 1994, pp. 255-257; Bruno 2018, p. 183). Hence, Bruno was confronted with the following problem: since matter is fundamentally in a state of mutation, and since stars and planets undergo change, as our Earth does, what guarantees that these primary bodies will not disintegrate over time (or at least not for a very long time) ${ }^{7}$ leaving the universe in chaos and general sterility? He answered this question clearly and concisely in his La Cena de le ceneri (Ash Wednesday Supper, 1584):

[. . .] given that annihilation of nature in its entirety is impossible, and that death and dissolution are not appropriate to the whole mass of this globe or star, from time to time, according to an established order, it is renewed, altered, changed, and transformed in all its parts. (Bruno 1994, p. 257; Bruno 2018, p. 183).

While most living things are born, enter into maturity then into decline, celestial bodies are different: they do experience life cycles, but only in their various parts; they continually recycle their matter in order to persist. So, Bruno explained how stars internally shift their material: "there is no part of a star which does not become the circumference or some other part, and there is no part on the outside or exterior which does not become the inside or interior" (Bruno 1994, p. 257; Bruno 2018, p. 185). And he supported this view by appeal to the Earth, that "certain things gather within the womb and bowels of the Earth, while others are ejected from them." (Bruno 1994, p. 257; Bruno 2018, p. 185). The key to a planet's flux is its motion in relation to its sun. In a universe without boundaries, the health of celestial bodies determines orderly change. Hence, the Earth revolves on its axis in order to spread heat and cold across its body. It revolves through its yearly course to experience seasons. It revolves around "its poles and antipodes" so that "there should be land where there was sea, cold where there was torrid, a tropical climate where there was an equinoctial one, and in all things incessant change" (Bruno 1994, p. 211; Bruno 2018, p. 153). By this latter motion, Bruno was referring to equinoctial precession. He devoted several extraordinary passages to the sweeping geographical and climatic changes that he takes precession to have caused. Rivers, lakes and seas can swell and dry up. Regions that were once marshy or cool become dry and hot. Lands inhospitable to agriculture become fertile. "Has the French climate not known great changes from Caesar's time to ours? At that time, there was no place where vines would grow, while now it produces more delicious wines than any other part of the world" (Bruno 1994, p. 265; Bruno 2018, p. 189). Bruno wrote that he had recently tasted grapes grown in the gardens of London and that they were considered the best ever produced by English soil. An expert at burning bridges, he added cheerfully that these fine English grapes were not yet so good as the worst produced in France.

Bruno's account of climactic change assimilated and transmuted Aristotle's Meteorology, namely Book I, chapter 14, wherein the Sun's course causes slow, long-term change to the global landscape; regions of dry land become sea and vice versa. "But," says Aristotle, "we must suppose these changes to follow some order and cycle" (Aristotle 1991, 351a19-351b4). Aristotle had compared vast terrestrial cycles to the life cycles of animals and plants, exactly as Bruno would. And, like Bruno, he had asserted that the Earth does not grow or decay as a whole, but "by parts". These terrestrial alterations are so slow that "before their course can be recorded from beginning to end whole nations perish and are destroyed" (Aristotle 1991, 351b9-352a17). Persistent alteration of rivers, seas and lands, causes pestilence and famine, which leads to outward migrations

Stars and planets undoubtedly enjoy a very long life, according to Bruno. But he is undecided on whether they disintegrate at some point. Because they are composed of contrary principles, physical considerations alone would suggest an eventual dissolution. Were they indeed eternal, this would be due to God. See Granada 2000. 
that happen slowly enough to be imperceptible. Likewise, when seas give way to land, incoming migration is gradual enough that the lapse of time hides the beginning of the process, as in Egypt's case, where the land accumulated from silt deposited by the Nile. Aristotle warned against linking these geographical transformations, as vast as they seem to the human perspective, with any wider cosmic evolution (Aristotle 1991, 352a18-352b15). Instead, we should think of them, he says, as cyclical. They are like the seasons. So, what has Bruno done with Aristotle here? In a recent study, Craig Martin has considered how Renaissance scholars dealt with the near absence of teleology in the Meteorology (Martin 2010), a conundrum since natural entities are supposed to act toward an intrinsic goal in Aristotle's physics. What kind of final cause could be behind meteorological vagaries and catastrophes, or, at a different timescale, behind the Earth's geographical shifts? Bruno put forth a telos. Great transformations in climate and landscape occur for the sake of the Earth's health. In turn, terrestrial lifecycle becomes cosmic lifecycle. Sweeping geographical change must count as a feature of all planets, just as the vital circuit of the Earth around the Sun provides a template for order in a boundless universe. It should also be added that spontaneous generation on the Earth, as Dilwyn Knox has noted, serves as the template for the variety of life on infinite globes. Nature, Bruno maintained, can even generate humans, as it has done after global cataclysms (Bruno 1884, p. 282; Knox 2019; Granada 2020). To summarize, the agency of Bruno's Earth is animal; its motions are directed towards the preservation of health. Planetary agency, in turn, serves as the fundamental, common cause of change in the cosmos.

Before turning to Kepler, I should first say something about William Gilbert. His De magnete, published when he was physician to Queen Elizabeth I, demonstrated the Earth to be a huge magnet, a discovery that would serve as a foundational piece of Kepler's physics. Gilbert was a Copernican, and he thought his magnetic philosophy offered a physics compatible with Copernican astronomy. Terrestrial magnetism, Gilbert believed, is evidence of self-conservation, self-cohesion and locomotion, themes that populate Book I of De revolutionibus orbium coelestium. De magnete also bears some trace of Bruno's thinking, in that Gilbert has the Earth rotating in order to spread heat equitably across its surface and so preserve life. ${ }^{8}$ If it did not turn, one face would burn and the other freeze; life would be impossible:

Therefore the bodies of the globes, as important parts of the universe, in order that they might be independent and that they might continue in that condition, had a need for souls to be united with them, without which there can be neither life, nor primary activity, nor motion, nor coalition, nor controlling power, nor harmony, nor endeavour, nor sympathy; and without which there would be no generation of anything, no alternations of the seasons, no propagation; but all things would be carried this way and that, and the whole universe would fall into wretchedest Chaos, the earth in short would be vacant, dead, and useless. (Gilbert 1900, pp. 209-210).

The unerring consistency of the Earth's motion, Gilbert believed, proves that its intellect must be greater than any human's. Humans make decisions based on sense, which can err, but the Earth relies on a perfect inner knowledge implanted by God (and, presumably, safeguarded against the Fall). The Earth's body must likewise be nobler than animal bodies. Gilbert goes so far as to sketch a hierarchy of living beings, with celestial globes between humans and what Gilbert calls "the divine intelligences", which "rise superior to every combination of organs". Hence, celestial bodies (including the Earth) do possess organs, although these organs are not constituted of flesh and blood. Gilbert goes so far as to assert that the organs are unimaginable to us humans, even if they must be there to carry out "organic activity". As for Aristotelians who would deny life to the Earth, Gilbert reminds them that life ennobles and that "God also [...] is a living soul" (Gilbert 1900, 208-210).

As mentioned, Kepler learned from Gilbert that the Earth was a great magnet. In fact, he went a step farther, ascribing a quasi-magnetic virtue to the Sun and making this force responsible for turning the planets. In his later physics, the interaction of the Earth's magnetic force with the Sun's causes our elliptical orbit, with its distinctive phases of acceleration and deceleration.

Bruno had resided in London from approximately April 1583 to October 1585 (Feingold 2004). 
Throughout all of his works, Kepler was clear that the active, vivifying forces in nature arise from animate bodies, that is, from embodied souls. Given the Sun's prodigious output of light, heat and quasi-magnetic force, the solar soul must be especially powerful, and its body especially dense (Kepler 1991, pp. 298-299). ${ }^{9}$ The Earth, in Kepler's natural philosophy, also requires a soul to power its diurnal motion. In addition, the Earth soul is a fount of creative generation in nature. It makes precious stones and lower forms of life from humid, corrupted matter. It delights in geometrical figures, setting them into flowers and crystals. When Kepler sought to explain how comets and new stars form in the endless reaches of nature, he used the Earth soul as a template for a cosmic soul, a genuine anima mundi (Boner 2013; Regier 2014). But Kepler's Earth soul is more than a powerhouse and principle of creative activity. It is also receptive and responsive. Here, we need to ask what exactly a soul is for Kepler. Whether belonging to a planet, plant, or animal, all souls are in one way the same. They are all essentially mathematical and carry within them every knowable proportion. ${ }^{10}$ This innate knowledge is their divine inheritance; it constitutes, quite literally for Kepler, the divine image reflected in creation. Souls thus spend their time engaging in mathematical activity: they seek proportion within sense data and compare it with their own geometrical structure. Where there is similarity, the soul experiences consonance; where there is dissimilarity, the soul experiences dissonance. This definition of the soul, found in the Harmonice mundi (1619), is tailor made to support Kepler's astrology (Kepler 1997, pp. 358-385). ${ }^{11}$ To put the matter very simply: planetary aspects express mathematical harmonies, which in turn affect the soul. Planetary aspects do not carry any power, just as musical intervals do not carry any special dancing force; rather, a listener's soul responds through its body. As Kepler wrote in one of his earliest works, "every animal faculty is the image of God practising geometry in creation, and is roused to action by this celestial Geometry or Harmony of Aspects" (Field 1984, p. 252). The Earth, then, reacts to mathematical proportions, and the most notable effect is meteorological. In addition, Kepler's Earth has sense organs. ${ }^{12}$ A stone thrown into a deep gulf or mountain lake will immediately stir up the weather: "For similarly also animals, if someone tickles the tender passages of their ears or noses by inserting something, are seized with horror, and shake their heads, or rush headlong into flight" (Kepler 1997, p. 365). This passage is actually a very good example of how Kepler talked about the Earth. Elsewhere in the same work, he compared it directly to "an ox or elephant", animals that are slow to anger but, once angry, "all the more violent" (Kepler 1997, 363). Kepler did not mean this metaphorically. He quite literally ascribed emotions to the Earth. He also ascribed desire to it, especially a sexual desire linked to its fertility role: "For it would not be easy for the Sun, destitute of suitable troops, to invade this citadel of the bowels of the earth, without the co-operation of some kind of soul, seated within, to collude with the enemy and open the gates to him" (Kepler 1997, p. 360).

I have mentioned the importance of terrestrial agency in Kepler's astrology. I would like to expand on this point, because sixteenth-century astrological work is a good place to look for earlymodern views on complexity. Astrologers frequently described their art as approximative because it involved so many diverse factors and local irregularities. Kepler grounded this complexity in physiology. I mean, for instance, that physiology allowed him to account for the delay and irregularity of astrological effects: animals do not simply respond to stimuli like brute mechanical systems do; they have their own prerogatives and complexities; they may take time to respond, respond with variability, or their response may be conditioned by a past event. Kepler believed all of these possibilities at play in astrological causality, including the Earth's memory of past events (Kepler 1997, pp. 369-370). He could also explain the power of irregularities, the incredible effects

9 For Kepler's veritable hymn to the Sun, see Kepler 1997, pp. 492-498.

10 Kepler eschews circular orbits as things of the mind, with no physical instantiation, but he does not eschew circles as epistemological. Instead, he bases all mathematical knowledge on the circle. Suffice it to say that he makes the circle the foundation of the Euclidean theory of proportion. See Regier 2016.

$11 \quad$ On Kepler and the Earth soul in the Harmonice mundi, see also Schwaetzer 1997.

12 Now, one obvious question is how an entity like the Earth perceives stellar rays. This issue is rather complex. Suffice it to say that Keplerian souls create a light in the body as their primary emanation; this light is perceptive. See Kepler 1997, p. 371, for the mechanism in question. 
of eclipses, new stars and comets. While such irregularities do not have any special power in and of themselves, they basically shock the system, leading to widespread sickness, "so that there is an immense and continual violence of rain, beyond that indicated by the aspects, or on the contrary drought and harshness, and associated earthquakes; and lastly there is unaccustomed dampness in the air, which brings pestilential catarrhs and other epidemic plagues [...]" (Kepler 1997, p. 369).

What can we take from the philosophies of Kepler and Bruno above, so quixotic and so 'Renaissance' to modern eyes? One takeaway, albeit superficial, would be to recognize the longevity and power of some analogies. In the 1990s, Wallace Broecker, one of the most eminent geoscientists at the time, called the climate an "angry beast" and warned that humanity was poking it with sticks (Russill, p. 115). James Lovelock writes about his affinity for metaphor in the Revenge of Gaia, saying that he never took the image of Earth as animal seriously but only found it instructive. Curiously, Lovelock writes that he never had a specific animal in mind but "always something large, like an elephant or a whale" (Lovelock 2006, p. 21). Kepler, we saw, also thought elephants made for a good comparison; they were slow to anger but, once upset, unstoppably ferocious. In any case, Lovelock stands by the need for metaphors:

[...] because to deal with, understand, and even ameliorate the fix we are now in over global change requires us to know the true nature of the Earth and imagine it as the largest living thing in the solar system, not something inanimate like that disreputable contraption 'spaceship Earth'. (Lovelock 2006, p. 21).

Stretches of Lovelock's writing come across like a procession of metaphors about the Earth, about exactly how we should consider it alive, as responsive to our activities. His style lends itself very nicely to Latour's program, and one gets a sense of why Latour so fully endorses the language of Gaia. ${ }^{13}$ In works over the last three decades, Latour has confronted contemporary ecological and political problems with the same basic project: creating and networking sense and agency, creating a surplus of meaning (e.g., Latour 2004, pp. 245-248; Latour 2014, pp. 16-17). The de-animation of nature has made any but the most opportunistic of relationships with the Earth impossible. It has removed all the stuff that produces relational bandwidth: understanding, reciprocity and boundaries.

There is something more that Ficino, Bruno and Kepler, can teach us. I would like to phrase it as a question: how could natural or terrestrial agency be more than a philosophical addendum to techno-scientific craft? In Bruno and Kepler, terrestrial agency solved fundamental problems, both physical and metaphysical. It was an embedded component of their conceptual architectures. Would a program like Latour's work if terrestrial agency did not figure in what Kuhnians call 'normal science'? In other words, would such a program work if it did not solve problems in the sciences of ecology and climate? Perhaps we may need to start by reconfiguring our view of human agency. For the figures we studied above, the structural resemblance between human and terrestrial proves to be a close one. In fact, the deep ecology movement in the 1970s took Spinoza as a source of inspiration precisely because Spinoza embedded the human completely within nature (Næss 1977; Kober 2013). We may already have a strong, contemporary paradigm of micro- and macrocosmic continuity ready at hand: the science and language of complex systems, systems ranging from human brains to economies and climates. The metaphor of the Earth as animal is, now as in the past, an intuitive way to relate to a complex being whose actions and responses are regular but inherently unpredictable. After all, complex systems produce interesting and non-trivial histories; they connect to their environments, sometimes in unimaginable and baffling ways. Moreover, to some extent, the terminology of complex systems (of non-linearity, emergence, feedback loops) has entered the popular mainstream. ${ }^{14}$ Just as we are a complex system—or, rather, an interweaving of complex systems - so is the Earth. Perhaps, the better we construe agency as a phenomenon common to many such systems, the better we can encourage and foster an

\footnotetext{
13 Latour also commends the way that Lovelock modifies his metaphors as he attempts to work against clichés and forge new descriptions. Latour 2017, pp. 69-70.

14 Beginning, for example, with James Gleick's Chaos in the late 1980s.
} 
appreciation of the Earth as agential. But even this seems naïve. I suspect most people are already happy to think of the Earth and its ecosystems as possessing some manner of agency, only a much lower kind in relation to the human. It seems to me that our unwavering sense of total superiority remains the most voluminous elephant in the room.

We certainly cannot turn back the clock. There are fundamental differences between our early-modern subjects and ourselves, differences that preclude any re-animation of nature in those older ways. The agency and sovereignty of natural entities was, for the early-modern authors above, undergirded by a belief that their God had imparted to living beings, including the Earth, the same basic kind of life that He had imparted to humans. They believed that the divine manifested in the many vital agencies of nature. To put the matter bluntly, all of them endorsed a kind of nature worship. Whether or not theology played a decisive role in tipping the philosophical scales toward mechanism, the latter, as its early-modern proponents knew, offered a clean separation of God and nature, a clear assertion of divine and human will. The political and economic utility of such a theology is obvious: a passive nature is a nature for the taking. But Gaia is not passive, nor a nurturing mother, nor an intellectual mother, nor any sort of mother. Gaia is not even a single being in the way a plant or animal is a single being. My worry is that we may need to fear the Earth - to fear the Earth, not any kind of Gaia-, and to fear it from our techno-scientific perspective. We might conclude on this point of fear. Perhaps one way to think of Latour's program is as an alternative to a most cynical kind of natural realpolitik, wherein non-human agencies can never be heeded unless they offer immediate and overwhelming threat.

\section{ACKNOWLEDGEMENTS}

I would like to thank Charles T. Wolfe, Miguel A. Granada and the anonymous referee for their suggestions. I would also like to thank Tina Asmussen and Pietro Daniel Omodeo for their feedback and for the invitation to contribute to this special issue.

\section{BIBLIOGRAPHY}

Aquinas, Thomas. 1917. Summa Theologica, translated by the Fathers of the English Dominican Province. New York, Cincinnati and Chicago: Benzinger Brothers.

Aristotle. 1991. The Complete Works of Aristotle, edited by Jonathan Barnes. 2 volumes. Princeton: Princeton University Press.

Barker, Peter. 1991. Stoic contributions to early modern science. In: Atoms, Pneuma and Tranquility: Epicurean and Stoic Themes in European Thought, edited by Margaret J. Osler. Cambridge: Cambridge University Press.

Barker, Peter. 2008. Stoic alternatives to Aristotelian cosmology: Pena, Rothmann and Brahe. Revue d'histoire des sciences 61: 265-286.

Boner, Patrick. 2013. Kepler's Cosmological Synthesis: Astrology, Mechanism and the Soul. Leiden: Brill.

Bruno, Giordano. 1884. Opera Latine conscripta, vol. 1.2, edited by F. Fiorentino. Naples.

Bruno, Giordano. 1889. Opera Latine conscripta, vol. 1.4, edited by F. Tocco and H. Vitelli. Florence.

Bruno, Giordano. 1994. Le souper des cendres [La cena de le ceneri], translation by Yves Hersant, text established by Giovanni Aquilecchia. Paris: Les Belles Lettres.

Bruno, Giordano. 2018. The Ash Wednesday Supper: A New Translation, translation by Hilary Gatti. Toronto: University of Toronto Press.

Cicero. 1967. De natura deorum. Academica, translated by H. Rackham. Cambridge, MA: Harvard University Press.

Copernicus. 1543. De revolutionibus orbium coelestium. Nuremberg: Johannes Petreius.

Dales, Richard C. 1980. The de-animation of the heavens in the Middle Ages. Journal of the History of Ideas 41: 531-550.

Darmon, Jean-Charles. 1994. Gassendi contre Spinoza selon Bayle: ricochets de la critique de l'âme du monde. Archives de Philosophie 57: 523-540.

Daston, Lorraine. 1995. How nature became the other: Anthropomorphism and anthropocentrism in early modern natural philosophy. In: Biology as Society, Society as Biology: Metaphors, edited by Sabine Maasen, Everett Mendelsohn, and Peter Weingart, pp. 37-56. Dordrecht: Springer. 


\section{AGENCY AND THE EARLY-MODERN EARTH}

Des Chene, Dennis. 2000. Life's Form: Late Aristotelian Conceptions of the Soul. Ithaca and London: Cornell University Press.

Feingold, Mordechai. 2004. Giordano Bruno in England, revisited. Huntington Library Quarterly 67: 329346.

Ficino, Marsilio. 1989. Three Books on Life, edited and translated by Carol V. Kaske and John R. Clark. Tempe: Arizona Center for Medieval and Renaissance Studies.

Ficino, Marsilio. 2001. Platonic Theology, vol. 1, translated by Michael J. B. Allen. Cambridge, MA: Harvard University Press.

Field, J. V. 1984. A Lutheran astrologer: Johannes Kepler. Archive for History of Exact Sciences 31: 189272.

Freudenthal, Gad. 1995. Aristotle's Theory of Material Substance: Heat and Pneuma, Form and Soul. Oxford: Oxford University Press.

Galileo. 1967. Dialogue Concerning the Two Chief World Systems-Ptolemaic \& Copernican, translated by Stillman Drake. $2^{\text {nd }}$ edition. Berkeley and Los Angeles: University of California Press.

Gassendi, Pierre. 2016. Examen de la philosophie de Robert Fludd, translated and edited by Sylvie Taussig. Milan: Archè.

Gilbert, William. 1900. On the Magnet (De magnete), translated by Silvanus Phillips Thompson. London: Chiswick Press.

Gleick, James. 1987. Chaos: Making a New Science. New York: Viking.

Granada, Miguel A. 2000. "Voi siete dissolubili, ma non vi dissolvete". Il problema della dissoluzione dei mondi in Giordano Bruno. Paradigmi 18: 261-289.

Granada, Miguel A. 2020. Conflagración en el Renacimento. Bruniana \& Campanelliana 26: 125-146.

Grant, Edward. 1994. Planets, Stars, and Orbs: The Medieval Cosmos, 1200-1687. Cambridge: Cambridge University Press.

Hirai, Hiro. 2011. Earth's soul and spontaneous generation: Fortunio Liceti's criticism of Ficino's ideas on the origin of life. In: Laus Platonici Philosophi: Marsilio Ficino and his Influence, edited by Stephen Clucas, Peter J. Forshaw and Valery Rees, pp. 273-299. Leiden: Brill.

Iliffe, Rob. 2017. Priest of Nature: The Religious Worlds of Isaac Newton. Oxford: Oxford University Press.

Kepler, Johannes. 1991. Johannes Kepler Gesammelte Werke, vol. 7, Epitome astronomiae copernicanae, edited by Max Caspar. Munich: C. H. Beck.

Kepler, Johannes. 1997. The Harmony of the World, translated by E. J. Aiton, A. M. Duncan, and J. V Field. Philadelphia: American Philosophical Society.

Knox, Dilwyn. 2005. Copernicus's doctrine of gravity and the natural circular motion of the elements. Journal of the Warburg and Courtauld Institutes 68: 157-211.

Knox, Dilwyn. 2019. Giordano Bruno. In: The Stanford Encyclopedia of Philosophy, edited by Edward N. Zalta. $<$ https://plato.stanford.edu/archives/sum2019/entries/bruno/>.

Kober, Gal. 2013. For they do not agree in nature: Spinoza and deep ecology. Ethics and the Environment 18 : 43-65.

Latour, Bruno. 2004. Why has critique run out of steam? From matters of fact to matters of concern. Critical Inquiry 30: 225-248.

Latour, Bruno. 2014. Agency at the time of the Anthropocene. New Literary History 45: 1-18.

Latour, Bruno. 2017. Why Gaia is not a God of totality. Theory, Culture and Society 34: 61-81.

López, Susana Gómez. 1999. 'Tellus animal magnum': Storia filosofica di una metafora. Intersezioni 19: 185207.

Lovelock, James. 2006. The Revenge of Gaia: Why the Earth is Fighting Back-and How We Can Still Save Humanity. London and New York: Penguin.

Martin, Craig. 2010. The ends of weather: Teleology in Renaissance meteorology. Journal of the History of Philosophy 48: 259-282.

Merchant, Carolyn. 1980 The Death of Nature: Woman, Ecology, and the Scientific Revolution. New York: Harper \& Row.

Næss, Arne. 1977. Spinoza and ecology. Philosophia 7: 45-54.

Park, Katharine. 2006. Women, gender, and utopia: The Death of Nature and the historiography of early modern science. Isis 97: 487-495.

Plato. 1925. Plato in Twelve Volumes, vol. 9. Timaeus. Critias. Cleitophon. Menexenus. Epistles, translated by W. R. M. Lamb. Cambridge, MA: Harvard University Press.

Plotinus. 2015. Plotinus Ennead IVI.3-4.29: Problems Concerning the Soul, edited, translated and with commentary by John M. Dillon and Henry J. Blumenthal. Las Vegas: Parmenides Publishing.

Plotinus. 2018. The Enneads, edited by Lloyd P. Gerson, translated by Boys-Stones et al. Cambridge: Cambridge University Press. 


\section{JONATHAN REGIER}

Regier, Jonathan. 2014. Kepler's Theory of Force and his medical sources. Early Science and Medicine 19: $1-27$.

Regier, Jonathan. 2016. An unfolding geometry: Appropriating Proclus in the Harmonice mundi (1619). In: Unifying Heaven and Earth: Essays in the History of Modern Cosmology, edited by Miguel A. Granada, Patrick J. Boner and Dario Tessicini, 217-237. Barcelona: Universitat de Barcelona.

Regier, Jonathan. 2019. "Qualis alio modo reperiri non potest". A few words on Copernican necessity. In: Contingency and Natural Order in Early Modern Science, edited by Pietro Daniel Omodeo and Rodolfo Garau, 115-136. Dordrecht: Springer.

Russill, Chris. 2011. Temporal metaphor in abrupt climate change communication: An initial effort at clarification. In: The Economic, Social and Political Elements of Climate Change, edited by Walter Leal Filho, 113-132. Dordrecht: Springer.

Schwaetzer, Harald. 1997. "Si nulla esset in Terra Anima" - Johannes Keplers Seelenlehre als Grundlage seines Wissenschaftsverständnisses: Ein Beitrag zum vierten Buch der 'Harmonice Mundi'. Hildescheim: Georg Olms Verlag.

Serres, Michel. 1995. The Natural Contract [Le contrat naturel], translated by Elizabeth MacArthur and William Paulson. Ann Arbor: The University of Michigan Press.

Wolfe, Charles. 2019. La philosophie de la biologie avant la biologie: Une histoire du vitalisme. Paris: Garnier. 